\title{
El centenario y la educación: la épica de la nacionalidad en debate
}

\author{
María Inés Rodríguez Aguilar ${ }^{1}$ \\ Museo Roca Instituto de Investigaciones Histórica (Argentina) \\ inesrodriguezaguilar@hotmail.com
}

Miguel José Ruffo²

Museo Histórico Nacional (Argentina)

miguelruffo@hotmail.com

Recepción: 24/05/2013

Evaluación: 29/10/2013

Aceptación: 13/12/2013

Artículo de Revisión

DOI: http:/ / dx.doi.org/ 10.9757/Rhela.22 / 04

\section{RESUMEN}

Se presenta una síntesis de la narrativa del relato pedagógico de 1910, en el contexto de la celebración del Centenario de los Sucesos de Mayo, articulada sobre algunos ejes temáticos que constituyen el campo educativo: la evolución normativa y la dinámica burocrática, las prácticas editoriales, protagonistas de gestiones nacionalizadoras y la alternativa de otras voces. Se han usado como fuentes editadas los informes y publicaciones oficiales (memorias y El Monitor Común), mensajes ministeriales $\mathrm{y}$, como bibliografía, textos y artículos de especialistas en historia de la educación y estudios culturales

Palabras clave: Revista Historia de la Educación Latinoamericana, dinámica burocrática, prácticas editoriales, textos nacionalistas, otras voces.

\footnotetext{
1 Licenciada en Historia y Archivista Universidad Nacional de Córdoba; Posgrado en Administración de Archivos Históricos y Administrativos. España, Docente en Universidad Nacional de Córdoba, Universidad de Buenos Aires, Universidad del Museo Social, Directora del Museo Roca (por concurso) desde 1985 Interventora en el Museo Histórico Nacional (2001-2002). Asesora de la Comisión de Historia de la Asociación Psicoanalítica Argentina (APA) desde 2008.

2 Doctorando Historia, Profesor y Licenciado en Historia por la Facultad de Filosofía y Letras de la UBA, - Jefe Área de Investigación del Museo Histórico Nacional.
} 
The centenary and education: The epic of the nationality in debate

ABSTRACT

It is presented a synthesis of the narrative of the pedagogical story from 1910, in the context of the celebration of the centenary of the events of May in relation with some themes that constitute the field of education: policy developments and the bureaucratic dynamics, the editorial practices, Protagonists nationalists managements and the alternative of other voices.

As editing sources there were official reports and publications (memories and El Monitor Común), and ministerial messages, such as bibliography, texts and articles by specialists in the history of education and cultural studies

Key words: Journal History of the Latin American Education, bureaucratic dynamics, Editorial practice, nationalist texts, other voices.
O centenário e a educação: A épica da nacionalidade em debate

RESUMO

Apresenta-se uma síntese da narrativa do relato pedagógico de 1910, no contexto da Celebração do Centenário dos Sucessos de Maio articulada sobre alguns eixos temáticos, que constituem o campo educativo: a evolução normativa e a dinâmica burocrática, as práticas editoriais, protagonistas de gestões nacionalizadoras e a alternativa de outras vozes. Foram usadas como fontes, os informes e publicações oficiais (memórias e O Monitor Comum), mensagens ministeriais e, como bibliografia, textos e artigos de especialistas em história da educação e estudos culturais.

Palavras-chave: Revista História da Educação Latino-americana, dinâmica burocrática, práticas editoriais, textos nacionalistas, outras vozes.

\section{INTRODUCCIÓN}

En la Argentina de 1910, en los contextos de la celebración apoteótica del Centenario de la Nación independiente, se entreteje una abigarrada superposición de estéticas y teorías: el liberalismo y el republicanismo heredados de los "padres fundadores", en un proceso de recomposición; un catolicismo impregnado de su derrota en las leyes laicas; el romanticismo tardío y acriollado, las corrientes realistas y naturalistas y el modernismo literario y cultural, en tensiones más explícitas con las vertientes del anarquismo y socialismo.

Desde 1852, luego de la caída de Rosas, la empresa de consolidar el programa político liberal de la modernización sobre los presupuestos del progreso en el marco institucional post-Caseros será diseño y obra de intelectuales, de acciones y vocaciones políticas, quienes paulatinamente articularán un campo intelectual en cuyo desenvolvimiento se entrecruzan protagonistas del quehacer científico y cultural ampliado, y cuyas gestiones específicas y tangenciales, a la par que sus producciones editoriales, circulan y se debaten ideas, problemas y proyectos. 
A partir de 1880, luego de la federalización, Buenos Aires, en tanto nueva capital, se consolidó como el núcleo político-administrativo y militar del estado liberal republicano, asentado en una ciudad metrópoli que ostentaba los atributos del poder económico, el centro de una nueva y dinámica economía agro-exportadora. La agro-exportación, la inmigración europea masiva y el movimiento internacional de capitales habían transformado en pocos decenios a la otrora Gran Aldea. La inmigración adquirió, en este complejo proceso, un ritmo creciente y vertiginoso. Hasta 1910 se radicaron en la Argentina alrededor de 1000000 de italianos, 700000 españoles. 90000 franceses, 70000 rusos (en su mayoría de origen judío), 65000 de origen árabe, 35000 centro europeos, 20000 alemanes y un número muy inferior de portugueses, belgas y holandeses. ${ }^{3}$

La dirigencia que administraba el Estado Nacional, ante la preocupación por la emergencia de una sociedad aluvial cosmopolita, optó, entre otras decisiones, por proponerse internalizar en la conciencia social valores culturales que relacionasen a la nueva sociedad inmigratoria con el pasado: el de las luchas independentistas que habían forjado a la Nación. Operatoria que incluía debatir los conceptos de argentinidad, rastrear la génesis de la sociedad republicana y definir un arquetipo de la nacionalidad. En esta trama de procesos culturales, la adopción de himnos, de banderas y la ritualización de conmemoraciones en liturgias cívicas desplegaron una compleja dinámica, vinculada a las diversas concepciones de las autoridades y a la emergencia y consolidación del estado nacional durante el Siglo XIX y XX.

El poder del estado era sostenido por una elite terrateniente en expansión comercial y financiera, a los cuales les resultaba indispensable entonces, rastrear la génesis de la nacionalidad, conceptualizar a la nación e instalar un conjunto de valores culturales e ideológicos y definir a la argentinidad, lo cual generó la necesidad de aglutinar a una sociedad heterogénea con una lectura del pasado, para proyectar esta visión de la nacionalidad hacia el futuro.

El clima cosmopolita, la consecuente circulación de diversas tradiciones sociales, culturales y lingüísticas de los inmigrantes y sus prácticas asociativas

3 Ema Cibotti, "Del habitante al ciudadano. La condición del inmigrante: La llegada", en Nueva Historia Argentina. El progreso, la modernización y sus límites (1880-1916) Tomo V, editado Por Mirta Zaida Lobato, (Buenos Aires: Sudamericana, 2000 ), 367. 
resignifican a la esfera pública. Este nutrido sector se constituyó en un conjunto social susceptible de ser nacionalizado e integrado al orden simbólico de la nación, aspiración ya propuesta con anterioridad por las diversas dirigencias.

En una configuración reticular, las ediciones de Anales, Mensuarios, Memorias y Anuarios serán las estrategias disponibles para sus editores, colaboradores y suscriptores las que se permiten reconocer itinerarios, desplazamientos e inserciones de los miembros de un amplio espectro de temática y vertientes. Revisiones minuciosas de estos ejemplares brindan indicios de las sugerentes relaciones dialógicas entre espacios del poder, pensamiento y evoluciones de trayectorias académicas y políticas, las que distan de ser lineales y sin tensiones.

Con estos sentidos, se despliega una diversificada operatoria, inscrita en el proceso de consolidación de la modernización de una sociedad y los procesos de consolidación del estado a partir de 1880, donde los órdenes simbólicos serían reformulados por sus elites dirigentes en un proceso fruto de la alquimia de pioneras producciones acerca de los mitos de los orígenes históricos de la nación como la Historia de Belgrano y La Independencia Argentina e Historia de San Martín y de La Emancipación Sudamericana; Vicente Fidel López en Historia de la República Argentina desde sus precedentes coloniales hasta el derrocamiento de la tiranía de 1852, publicada en diez volúmenes entre 1883-1893, o en Historia de la República Argentina, Su origen, su revolución hasta 1852, autores de prácticas culturales heterogéneas e irreductibles polémicas que encendieron el núcleo de los debates historiográficos de SXIX. ${ }^{4}$

Diversos relatos históricos de implicaciones potenciales hacia otros actores y lecturas diferenciadas de procesos posibilitaron una interpelación a estas imágenes del pasado nacional, entre ellos Adolfo Saldías (1881) con su protorevisionismo, en la Historia de Rosas y su época, luego, revisada y reeditada en 1892 con el título de la Historia de la Confederación Argentina; El Federalismo Argentino (1887) de Francisco Ramos Mejía y Joaquín V. González, con la reivindicación de las raíces indígenas en La Tradición Nacional (1888), de una imagen más matizada de los orígenes. ${ }^{5}$

4 Roberto Madero, El origen de la Historia, sobre el debate entre Vicente Fidel López y Bartolomé Mitre, (Buenos Aires: Fondo de Cultura Económica:, 2001), 47. Tulio Halperín, Vicente Fidel López Historiador, (Buenos Aires: El cielo por asalto, 1996$), 65$.

5 Fernando Devoto, Nacionalismo, fascismo y tradicionalismo en la Argentina moderna. Una historia, (Buenos Aires: Siglo XXI, 2002), 13. Fernando Devoto y Nora Pagano, Historia de la Historiografía, (Buenos Aires: Sudamericana, 2009) 23-34. 
Estos intelectuales, que ejercían con ciertos grados diferenciados una funcionalidad a la elite hegemónica, aspiraban a convertir sus producciones en el relato ideal del pasado común, para lo cual disponían espacios institucionalizados, productos de las articulaciones surgidas a partir de la Ley 1420 de Educación de 1884, que establecía la enseñanza laica, gratuita y obligatoria, con contenido en su currículum de las siguientes materias: historia nacional, geografía nacional y lengua castellana.

Tempranamente, desde el inicio de la etapa constitucional de 1853, la dirigencia que proponía el valor absoluto del progreso había asignado a la educación una función política al concebirla como una herramienta de cambio social y formación de ciudadanía, generando interrogantes y debates sobre la eficiencia de esta, los límites del cambio social en la modernización y las condiciones de ejercicio de los derechos políticos.

Estas encendidas controversias de los modelos de sociedad y la percepción de la educación, concebidas como una mediación política y social para la formación de ciudadanía, enfrentadas con la que impulsaban la vinculación del sistema educativo al aparato productivo, generaron debates que circularon en los textos de Sarmiento La Ciento y una y en las Cartas Quillotanas de Alberdi. ${ }^{6}$

En paralelo con los primeros arribos de inmigrantes, paulatinamente comenzará a conformarse la "cuestión migratoria" interpretada como un factor de modernización para una sociedad definida como tradicional. Este fenómeno "aluvional" generará complejos procesos cuyos ejes problematizarán de manera creciente a los múltiples dilemas y tensiones de la dinámica de la construcción social y cultural. ${ }^{7}$

\section{Un largo itinerario: de La Ley 1420 de 1884 al Centenario}

El largo conflicto entre la Confederación y Buenos Aires (1852-1862) dificultó la implementación de un sistema educativo "nacional" centralizado, para una realidad que ostentaba una imperiosa necesidad de transformación y

6 Torcuato di Tella, "Raíces de la controversia educacional en la Argentina", en Educación y Sociedad 1880-1945, editado por Facultad de Filosofía y Letras (Buenos Aires: Facultad de Filosofía y Letras-Siglo XXI), 23-34.

7 Hilda Sábato y Ema Cibotti, “Inmigrantes y Política: un problema pendiente”, Estudios Migratorios 4 (1986): 25- 35. Tulio Halperin, El Espejo de la Historia, (Buenos Aires: Sudamericana, 1997), 192-275. Fernando Devoto y Héctor Otero, "Veinte años después una lectura sobre el crisol de razas, el pluralismo cultural y la historia nacional en la historiografía”, Estudios Migratorios, Latinoamericanos, Año 1, 7, 50 (2003): 181-227 
evidenciaba diversidad y fragilidades de diferentes grados, de acuerdo con sus contextos locales y sus tradiciones.

En este período el Estado de Buenos Aires, luego de intentos sin definiciones claras de descentralizaciones y pertinencias inestables que no solucionaron la organización educacional, logró recuperar y estabilizar a establecimientos y dinámicas institucionales, en especial concretar un progreso educativo significativo con la gestión de Domingo F. Sarmiento como, Jefe del Departamento Educativo (1856-1861), quien a partir de los presupuestos de su texto Educación Popular de 1849, orientó su acción innovadora de influencia pestalozziana y froebelianas, la que contó con la estrecha colaboración de la excepcional Juana Manso (1819-1875) en el impulso de la publicación de textos escolares y los Anales de la Educación Común. Además dotó a las escuelas de rentas propia en 1857 y promovió la construcción de sólidos y bellos edificios escolares, en la ciudad de Buenos Aires y casas escuelas en el territorio provincial. ${ }^{8}$

Las teorizaciones medulares del texto junto a los minuciosos procedimientos sobre la administración de instituciones escolares de la Educación Popular y La Educación Común (1855) orientan las prácticas y reglamentaciones educativas en la ciudad de Buenos Aires, donde en 1854 el estado autónomo de la provincia de Buenos Aires dictó junto con la Constitución, la ley de Municipalidades que establece una organicidad del Estado de la ciudad, cuyo órgano ejecutivo instauraba una Corporación Municipal de 21 municipales y un vicepresidente. El cargo de presidente quedaba reservado para el Ministro de la Provincia.

Las elecciones de marzo de 1856 permitieron a calificados hombres de la cultura y el pensamiento de la generación romántica iniciarse en la política y gobierno en una ciudad de 91000 personas de vertiginoso proceso de urbanización y crecimiento demográfico por la llegada de inmigrantes, y así en 1869 contaba con 187346 habitantes. Ese número trepó a $407900{ }^{9}$

\footnotetext{
8 Juan Cassani, "Doctrinas pedagógicas de Sarmiento". En Humanidades, Tomo XXVI, editado por Facultad de Humanidades y Ciencias de la Educación de la Universidad de La Plata, 55-65. (La Plata: Facultad de Humanidades y Ciencias de la Educación de la Universidad de La Plata, 1938). Juan Mantovani et. al, Sarmiento, educador, sociólogo, escritos y político, (Buenos Aires: Universidad de Buenos Aires, Facultad de Filosofía y Letras, 1963), 264. Maristella Svampa, El dilema argentino. Civilización o barbarie. De Sarmiento al revisionismo peronista, (Buenos Aires: Ediciones El cielo por asalto, 1994), 11-17. Juan Carlos Tedesco, Educación y Sociedad 1880-1945, (Buenos Aires: Siglo XXI, 2009), 23-34.

9 Dirección General de Patrimonio, e Instituto Histórico, "La Educación Pública. Del municipio a la Nación (1857-1886)", (Buenos Aires: Dirección General de Patrimonio e Instituto Histórico, 2011$) 7$.
} 
La educación pública de la ciudad de Buenos Aires estuvo administrada conjuntamente por el Departamento general de Escuelas de la provincia de Buenos Aires, el Consejo de Instrucción Pública (Pcia de Buenos aires), la Municipalidad y la Sociedad de Beneficencia, en una etapa de complejidad burocrática, fuente de experiencia y utilidad en futuras tareas de gestión educativa. ${ }^{10}$

La mencionada Ley de Municipalidades la responsabilizó del financiamiento y la vigilancia de la instrucción pública poniendo los establecimientos de varones a cargo de una Comisión Municipal de Educación. A mediados del siglo XIX el $50 \%$ de las niñas en edad escolar se educaban en las escuelas dirigidas por la Sociedad de Beneficencia, creada con el objeto de administrar de un sistema de escuelas públicas elementales femeninas, la reorganización de las escuelas de San Miguel y la creación de un orfanato para niñas.

El financiamiento de estas instituciones estaba a cargo del Estado y la administración era ejercida por mujeres de la élite porteña, presidida por Mariquita Sánchez, "anfitriona republicana" en la sociabilidad posrevolucionaria, interesante protagonista que inicia una fuerte polémica con Sarmiento, Jefe del Departamento General de Escuelas (1856 -1862) quien ataca en sus Informes y en la Revista Anales de la Educación. ${ }^{11}$ En lo pertinente a la organización educacional, la aplicación de políticas eficientes se tradujo en una sólida trama de prácticas e instituciones que tendrán proyección nacional, luego de la federalización y la consolidación del estado nacional.

Las Presidencias de Mitre, Sarmiento y Avellaneda, pese las críticas situaciones motivadas por la Guerra de Paraguay (1865-1870) aceptaron el desafío de diseñar e implementar la política educativa de acuerdo con lo que La Constitución Nacional de 1853 establecía en su Art. 5º que el sostenimiento de la educación primaria era condición indispensable para que la provincias gozarán de sus autonomías; y el Art. 67, al referirse a las atribuciones del gobierno nacional, establecía que le correspondía dictar planes de instrucción general y universitaria, sin aclarar si las facultades de Nación y de las Provincias eran exclusivas o recurrentes.

10 Ibid., p.11.

11 Graciela Batticuore, La mujer romántica, Lectoras, autores y escritores en la Argentina: 1830-1870, (Buenos Aires: Ensayo EDHASA, 2009), 89 y 175. 
Las posteriores transformaciones del campo educativo (1862-1880) inscribirán un complejo itinerario de debates de proyectos y acuerdos, de normativas y prácticas de los diversos niveles administrativos y educativos, en los cuales modelos ideológicos y científicos y modelos heredados son apropiados y reelaborados de acuerdo con las dinámicas sociopolíticas locales.

Se adoptan numerosas normativas, Decretos que crean las Escuelas Normales (1869 y 1870), la Ley Nacional N ${ }^{\circ} 463$ de 1871, la Ley de Subvenciones Nacionales, regulando la administración de fondos y las misiones y funciones de las Comisiones Provinciales (de elección directa por el vecindario), y los inspectores provinciales (designados por la Comisión); La Ley de Educación Común de 1875 que rige para la provincia de Buenos Aires y en la que crea la Comisión Nacional de Educación (con un Director General y ocho vocales), órgano que más tarde en 1876, sanciona el Reglamento General de Escuelas (vigente hasta 1887), complementadas por la Ley No 934 de 1878 sobre la Libertad de Enseñanza que regulaba las situaciones de los alumnos de establecimientos particulares. ${ }^{12}$

En este período se formularon instituciones estructurantes del campo de la educación intermedia con carácter nacional, que ya contaba con los valiosos antecedentes del Colegio de Concepción del Uruguay y otras experiencias. En 1863 sobre el antiguo Colegio y Seminario de Ciencias Morales emerge el Colegio Nacional de Buenos Aires, "una casa de educación científica preparatoria, en la que se cursarán las Letras y las Humanidades, las Ciencias Morales y las Ciencias Físicas". Los fines concebidos desde el enciclopedismo y el positivismo "ayudarán a aquella juventud que la patria les confía su porvenir", en el cual la consolidación institucional del Estado funcionó como condición de posibilidad de conformación de una elite política nacional, de heterogéneas procedencias, que entre otras variables se postuló sobre la base del capital cultural y formación intelectual, contribución de la expansión de los colegios nacionales que la dotará con "las armas mejor templadas desde las cuales se gobierna a los pueblos". ${ }^{13}$

\footnotetext{
12 Juan Ramos, Historia de la Instrucción Pública en la República Argentina (1810- 1910) Atlas Escolar, Tomo I Consejo Nacional de Educación Conmemoración del Centenario de 1810, (Buenos Aires: Peuser, 1910), 381-385. Leoncio Gianello, "La enseñanza Primaria y secundaria (1862-1930)" en Historia Argentina Contemporánea (1862-1939) Vol. II Historia de la Instituciones, editado por Academia Nacional de la Historia, 130-148. (Buenos Aires: Academia Nacional de la Historia, 1964), 131. Adriana Puiggrós, Sujetos, Disciplina y Currículum en los orígenes del sistema educativo argentino (1885-1916), (Buenos Aires: Editorial Galerna, 1990), 37-49.

13 Gianello, “La enseñanza Primaria y secundaria (1862-1930)", 120.
} 
Tras algunos intentos y con la inspiración sarmientina, en 1870 fue creada la Escuela Normal de Paraná, cuyo objetivo era "la formación de maestros competentes para las escuelas comunes", garantía del modelo normalizador de la educación primaria, dirigido por el pedagogo norteamericano Jorge Stearns. Se inició así una etapa fundamental para el sistema educacional, donde se destacará el español José María Torres, con su pensamiento

fundante del eclecticismo pedagógico normalista, formulado en sus obras, labor docente y su ejercicio en gestiones burocráticas. ${ }^{14}$

Estas institucionalidades aspiran a formar los dirigentes y maestros, instrumentos para la construcción de "una nación cívica", que sostendrían a la hegemonía liberal en los ejercicios de responsabilidades políticos-administrativas, y a la acción educadora que formaría a los ciudadanos industriosos, fieles al estado y que eliminarían la heterogeneidad de sus procedencias.

\section{La cultura del normalismo}

Una multiplicidad de normativas ordenaron a las gestiones educativas de todos los niveles, a los contenidos curriculares y a los usos de los dispositivos pedagógicos, hasta que la síntesis de la Ley 1420 de Educación Común (1884), consagró la gratuidad, obligatoriedad y laicidad de la enseñanza y otorgó las formas institucionales que consignan el carácter hegemónico del Estado en la educación, en la estructura política administrativa del sistema y en la trama profunda de los discursos pedagógicos de tono positivista o espiritualistas, donde convivían, no sin encendidas polémicas y tensiones, una multiplicidad de tendencias político-educativas que aún se despliegan las primeras décadas del siglo XX. ${ }^{15}$

Estos intercambios ideológicos subyacen durante esta etapa en sectores impregnados de "tradición regalista y católica", en donde la aspiración del pluralismo religioso emprende un camino de construcción apoyados en la neutralidad de la constitución nacional en materia de educación.

14 Juan Manuel Chavarría, La escuela normal y la cultura argentina (Buenos Aires: El Ateneo, 1947), 45. Juan Carlos Tedesco, Educación y Sociedad 1880-1945, (Buenos Aires: Siglo XXI, 2009), 143. Sandra Carli, Niñez, Pedagogía y Política, Transformaciones de los discursos acerca de la infancia en la historia de la educación argentina entre 1880- 1945, (Buenos Aires: Universidad de Buenos Aires \& Miño y Dávila, 2009), 78.

15 Tedesco, Educación y Sociedad 1880-1945, 143. Adriana Puiggrós, Sujetos, Disciplina y Currículum en los orígenes del sistema educativo argentino, 78 . 
Con estos sentidos, Sarmiento, desde una encendida tribuna, proponía una moral civil, combinación de elementos racionalistas y religiosos, la neutralidad del Estado con fuertes críticas "al clericalismo y al control ultramontano del aparato gubernamental, anhelando una cultura semejante a la norteamericana, cuya vitalidad se sostenía en la falta de unidad de creencias". ${ }^{16}$

Promulgada la Ley 1420, de vigencia en la Capital Federal y Territorios Nacionales y de las disposiciones adoptadas por las provincias pertinentes, se configuró un sistema de instrucción pública al determinar los principios generales de la enseñanza en la escuela primaria, que según el Art. $1^{0}$ "tiene por único objeto favorecer y dirigir simultáneamente el desarrollo, moral intelectual y físico de todo niño de seis a catorce años de edad", cristalizando así al imaginario sarmientino de afirmadas premisas: una generación escolarizada, era la condición indispensable para un país moderno y la escolarización de la infancia, devendría en un fenómeno constitutivo de la sociedad y la cultura moderna argentina y la garantía del orden social. ${ }^{17}$

Luego, en un amplio articulado y posteriores reglamentaciones se aplicaron criterios ordenadores, en planes y reglamentos que consolidaron la expansión del normalismo, como cultura pedagógica hegemónica, atravesada por el debate entre positivistas y kraussopositivistas que resignifican a las tradiciones y genealogías pedagógicas, en el campo discursivo de la instrucción pública, en el que circulaban discursos antagónicos y marginales a las instituciones oficiales, percibidos como radicalizados, los que hacia 1910 enriquecieron el debate, pero que no se establecieron como alternativas.

El sistema educativo se expandió con éxitos desiguales por el territorio, de acuerdo con la diversidad de políticas y participación y compromiso de las dirigencias locales. Asimismo, se determinaron los planes de estudios y se dictaron reglamentos de los colegios nacionales y se designó a la comisión para proyectar un plan de estudios para las escuelas normales y de profesores, adoptando el criterio de fortalecer el carácter nacional de los contenidos en historia y geografía argentina e instrucción cívica porque "la escuela es la refundición pacífica de las diversas creencias y tradiciones en un solo crisol". ${ }^{18}$

16 Natalio Botana, Los nombres del Poder. Domingo Faustino Sarmiento, (Buenos Aires: Fondo de Cultura Económica, 1997$), 64$.

17 Roberto Marengo, "Estructuración y consolidación del poder normalizador: el Consejo Nacional de Educación", en Sociedad Civil y Estado en los orígenes del sistema educativo argentino, editado por Adriana Puigros, (Buenos Aires: Editorial Galerna, 1991), 75 .

18 Ministerio de Justicia e Instrucción, Memoria de Instrucción Pública Tomo II (Buenos Aires: Peuser, 1886), 465. 
Su organización burocrática tuvo como núcleo de la acción político institucional al Consejo Nacional de Educación, quien articula las orientaciones emanadas del Gobierno Nacional respecto de la educación, al implementar una gestión institucional concentrada y de amplia cobertura territorial en Consejos locales, un cuerpo de inspectores técnicos y los órganos de consulta sobre temas específicos: de perfeccionamiento y actualización docente, selección de textos, conferencias pedagógicas, higiene y arquitectura escolar, etc., instalando un aparato burocrático de estable permanencia. ${ }^{19}$

A partir de la Ley 1420 y su irradiación de territorialidad, los órganos paulatinamente erigidos se regularon por sucesivos reglamentos y se integraron dinámicamente por una circulación en diversas funciones de sus destacados miembros, pertenecientes a la denominada "cultura científica" y a la "estético humanista", de diversos matices y prestigios e implementaron las gestiones de regulación e inspección, las que debieron enfrentar problemáticas de larga data, como la deserción escolar, la capacitación y reclutamiento docente, la indefinición de los objetivos de la enseñanza intermedia y la complejidad de las especificidades regionales y situaciones institucionales.

Estas gestiones, caracterizadas por la expansión y conflictividades implícitas o explícitas de resoluciones y acuerdos, en tonos mediadores o verticalistas autoritarios, articularon un campo educativo impregnado hasta 1910 por la "cuestión nacional", hegemónica polémica devenida a partir de la política de un asimilacionismo intransigente sobre la formación de la nacionalidad, propuesta por las articulaciones de tendencias tradicionales de diverso cuño y cuestionadas por la emergencia de corrientes pedagógicas renovadoras.

A partir de esta etapa, el sistema educativo se instrumentó como el escudo que resguardaría a la vulnerable sociedad criolla en transición a la modernización e hibridación, adoptando prácticas, símbolos, contenidos nacionales, ritualidad en las celebraciones de las fiestas patrias, sumadas a las dispuestas por una diversidad de agrupaciones de la esfera pública.

Se adoptó una multiplicidad de estrategias, con el fin de promover una conciencia cívico-patriótica en la infancia y juventud escolarizadas y anclar

19 Roberto Marengo, “Estructuración y consolidación del poder normalizador: el Consejo Nacional de Educación”, en Sociedad Civil y Estado en los orígenes del sistema educativo argentino, editado por Adriana Puigros, (Buenos Aires: Editorial Galerna, 1991),92. 
en la memoria una selección de acontecimientos fundantes, proyectados utópicamente hacia el futuro, al que convirtieron en destino de una sociedad que debía reconocerse como la nación argentina, una república liberal nacida en la gesta de mayo. ${ }^{20}$

El campo educativo, producto la relaciones dinámicas y complejas de las diversas gestiones ministeriales y de los órganos de instrumentación nacional (de alcance a los amplios territorios nacionales) en todos los niveles de la enseñanza, en relaciones con los provinciales, generó una "temporalidad educativa" pautada desde el estado, que comienza a ser in1terpelada por los sucesos de la "temporalidad política", la que presenta signos de disconformidad al estallar la Revolución del noventa, por reclamos de las fuerzas políticas emergentes de la nueva constitución de la sociedad; Demandas crecientes que aspiraban a reformar el sistema político, las prácticas cívicas, y abordar las problemáticas de amplio espectro, definidas como la "cuestión social". ${ }^{21}$

Estos procesos educativos no se articulan funcionalmente con la esfera de la política y la economía, ni muestran correspondencias estables o lineales, pero su evolución, arbitrada por modificaciones graduales de muy diferenciadas eficiencias y éxitos, se inscribe en un complejo relacional abierto que remite a específicas y dinámicas situaciones históricas. Por lo tanto, establecer una única periodización cronológica para la historia de campo educativo será siempre una operación arbitraria. ${ }^{22}$

Estas vinculaciones complejas traman las relaciones entre los mencionados procesos educativos y las transformaciones institucionales integrales de un Estado, que evolucionó hacia una creciente profesionalización de las funciones burocráticas vinculadas a la educación, con una participación de los "expertos" en la elaboración de sus políticas públicas. Es en este sentido, en el ámbito educativo ejercerán destacas funciones abogados, médicos, catedráticos universitarios, quienes conformarán una "inteligencia pedagógica" de diversidades ideológicas, que enfrentará el tránsito del siglo XIX. Y la primera década del siglo XX desempeñando gestiones y produciendo sabe-

20 Lilia Ana Bertoni, Patriotas, cosmopolitas y nacionalistas. La construcción de la nacionalidad a fines del siglo XIX, (México: Fondo de Cultura Económica, 2001), 260.

21 Eduardo Zimmerman, Los liberales reformistas. La cuestión Social en la Argentina (1880-1916), (Buenos Aires: Editorial Sudamericana y Universidad de Andrés, 1995), 11.

22 Tedesco, Educación y Sociedad 1880-1945, 143. Puiggrós, Sujetos, Disciplina y Curriculum, 33. 
res de acuerdo con las orientaciones de un reformismo liberal de diversas genealogías, confluencias y matices.

La fractura política de 1890, emergida de las crisis de las alianzas que garantizarían la estabilidad del régimen y de los límites del proyecto modernizador, también evidenció las escasas potencialidades de la "oposición cívica" para articular una estructura política con capacidad de una rápida transformación del régimen cuestionado. El desafío de enfrentar las consecuencias, la crisis económica y los reclamos de nuevos sectores políticos que aglutinaban a los nuevos actores sociales, evidencia de la complejidad de la modernización, incidieron en la reflexión y balance de las transformaciones que el sistema educativo había alcanzado. ${ }^{23}$

Así, en marzo de 1891, aparece un informe de una Comisión de destacados miembros de la burocracia educativa, afirmando que la instrucción primaria no debe sufrir reformas radicales y poniendo en cuestión las deficiencias de la enseñanza intermedia, que, de acuerdo con informes de autoridades en 1893, adolecía del "enciclopedismo de sus programas" y se calificaba de "superficial y homeopática". Ante esta situación, los responsables de formular las soluciones intentaron orientar a la enseñanza al adoptar el criterio de atender los reclamos y al proponer una orientación técnica y profesional, con el convencimiento de satisfacer así las demandas sociales y políticas, evaluadas como medidas "conservadoras", pues habilitarían una reproducción del esquema social, quedando para las élites los cargos burocráticos y la formación universitaria. ${ }^{24}$

En 1897 se envían a la Cámara de Diputados nuevos proyectos, luego que hacia el fin de siglo se había fundado la Escuela Industrial de la Nación y se habían intensificado los estudios contables, entre ellas la primera escuela comercial para mujeres, además de las escuelas normales mixtas. El debate sobre la reorientación de los fines de la enseñanza intermedia y la promoción de establecimientos con orientaciones técnicas o sociopolíticas se encendió al presentarse al Congreso en 1899 el plan reformista del gobierno conservador sobre Enseñanza General y Universitaria, cuando los nuevos sectores sociales en ascenso exigían una mayor participación política. Los debates se desplegaron en torno a "la actitud modernizante de la oligarquía como la

23 Juan Carlos Tedesco, Educación y Sociedad 1880-1945, (Buenos Aires: Siglo XXI, 2009), 155.

24 Ministerio de Insrucción Pública, Memoria de Instrucción Pública Tomo II, 6. 
reacción tradicionalista de los sectores medios", en las intervenciones del Ministro de Instrucción Pública del segundo gobierno de Roca, Dr. Osvaldo Magnasco y de los diputados de la oposición Carbó, destacada y elocuente, Castellanos y Balestra, quienes colocaron en el núcleo de las discusiones y de los intercambios a las diferentes visiones de la sociedad y del sistema educativo, que presenta "la necesidad de una enseñanza especial para la clase dirigente", las que recuperaron el dilema de una tradición de Alberdi "con respecto a la enseñanza técnica: la industria es el calmante social por excelencia". Se debatieron de manera tangencial el control y mantenimiento del sistema en las provincias, que encontrará una cierta resolución en la sanción de la denominada ley Laínez en 1905. ${ }^{25}$

\section{Saberes, prácticas editoriales y políticas educativas}

El período entre 1880 y 1910 -la dinámica del mundo editorial inscripta en las modificaciones culturales de la modernización capitalista (urbanización e industrialización)- generó una expansión y crecimiento de la producción y consumo de una diversidad de objetos impresos, fenómeno que entre otros universos de lectores tuvo al "público infantil como destinatario, debido, por una lado, a la expansión de la escolarización y la consiguiente producción discursiva acerca de la infancia" y una creciente modernización de la industria de la impresión, con nuevas maquinarias, obreros gráficos y editores altamente calificados. Para 1887 en la ciudad de Buenos Aires, circulaban “3379040 ejemplares de las más diversas publicaciones periódicas, médicas, en lengua extranjera, comerciales, religiosas y educativas", fenómeno consolidado luego de la crisis de 1890 con un mayor desarrollo a partir de la introducción de la linotipo en $1901 .{ }^{26}$

En este contexto, al universo del texto escolar "objeto de doble faz, económica y simbólica, es a la vez mercancía y significación”, se le aplicarán resoluciones para regular su elección y su distribución, funciones que se delegan a la Comisión de Textos, reglamentada en 1887. A modo de ejemplo:

Comisión revisora de Textos de 1897: Lectura: Prof. P. Pizzurno, la Rec. de la Escuela Normal Amalia Gramondo, Idioma Nacional: Dr. Joaquín $V$ Gonzalez y Osvaldo Magnasco (ambos futuros ministros) y Rafael

25 Juan Carlos Tedesco, Educación y Sociedad 1880-1945, (Buenos Aires: Siglo XXI, 2009), 169.

26 Damián Bil, Descalificados. Proceso de trabajo y clase obrera en la rama gráfica (Buenos Aires: Ediciones R y R, 2007 ), 32. 
Obligado, Historia: Dr. Indalecio Goméz y Mariano Paunero. Geografía: Dr. Estanislao Zeballos. Instrucción Moral y Cívica: Dr. Luis Peyret. Dr. Hipólito Irigoyen, Marcos Avellaneda, Manuel a. Montes de Oca y Carlos Rodríguez Larreta. Ciencias Físicas y Naturales: Dr. Eduardo Holmberg e Idelfonso Ramos Mejía. Dibujo: Sixto Quesada y el pintor Eduardo Sivori, Geometría: Ing. Ángel Gallardo (futuro presidente del CNE), Trabajo Manual Trufó. Economía, labores y Corte y Confección: Ins Ursula Lapuente. Higiene: Dr. José Ma Ramos Mejía (futuro presidente del CNE), el jefe del Cuerpo Médico:Dr. A. Valdéz y Dr. José Penna ${ }^{27}$

Esta comisión estaba integrada por intelectuales, políticos, artistas y editores de revistas científicas, quienes en los decenios siguientes desempeñarían importantes funciones jerárquicas y desarrollarían intensas labores culturales. Debían analizar los contenidos y sentidos la literatura didáctica para determinar las listas de materiales aprobados y de adquisiciones del Ministerio, interviniendo así en las redes de intercambio entre editoriales, los autores y los centros inspiradores de las formaciones pedagógicas, los que orientaban en el tratamiento de los contenidos de programas, los que se vieron en ocasiones sujetos a polémicas como la propuesta de la Comisión de Didáctica del Consejo Nacional de Educación de permitir la libre elección de los textos, la cual se rechaza, lo que evidencia las contradicciones del sistema propuesto desde el liberalismo.

Los textos devinieron en "las herramientas con que los proyectos que combinaron la modernización y la creación-consolidación de las estructuras nacionales, hicieron frente a las diversidades" ${ }^{28}$ de acuerdo con sus autores, sus contenidos y la circulación impuestas por el CNE, se constituyeron en objeto de estudio por especialistas de diversas disciplinas y ópticas de algunas tensiones.

En una amplia proporción, los textos escolares, en el sentido de las refinadas reflexiones de Podgorny, comparten dos elementos: integran la dinámica de la empresa editorial y tienen por "objeto educar y socializar gradualmente a sus lectores", por medio de esquemas moralizadores y textos históricos que se formulan desde el peso de las tradiciones historiográficas, resignifica-

27 Roberto Marengo, “Estructuración y consolidación del poder normalizador...”, 92.

28 Alejandro Eujenian, "La cultura: público, autores y editores". En Liberalismo, Estado y Orden Burgués, Nueva Historia Argentina, Tomo IV, editado por Marta Bonaudo, 545-605, (Buenos Aires: Sudamericana, 1999), 547. 
das por las adscripciones ideológicas de sus autores, los que incluyen unas diferenciadas valoraciones de procesos y actores sociales al amparo de la impronta de impregnar de sentidos nacionalizadores a los textos, sentidos densamente patrióticos o americanistas, según ciertos autores y las recomendaciones impuestas desde Consejo Nacional de Educación.

Las empresas adecuan sus políticas empresariales a las educativas, que incluyen a las ediciones tradicionales, a textos renovadores de nuevas temáticas pedagógicas y a materiales de colecciones didácticas, todos de alta calidad editorial y estética en compaginación e ilustraciones, y variedades estilísticas en la línea del dibujo. El órgano oficial de divulgación del Consejo Nacional de Educación será la revista el Monitor de la Educación Común, que incluía una Sección Oficial con todas las noticias del Consejo Nacional de Educación, cuya edición era responsabilidad del Superintendente General de Escuelas: “dirigir una publicación periódica en que se inserten todas las leyes, decretos, reglamentos, informes, y demás actos administrativos que se relacionen con la Educación Primaria, como asimismo los datos y conocimientos tendientes a impulsar su progreso". ${ }^{29}$

Se conformó un dinámico espacio estratégico, portador de saberes específicos e informaciones estadísticas y generales sobre educación, los que difundieron formulaciones, conceptos y elecciones teóricas o político ideológicas de las tendencias pedagógicas circulantes y configuraron, en confluencia a otras prácticas editoriales paralelas, una fecunda pluralidad de discursos. El Monitor incorporó paulatinamente la evolución de las publicaciones periódicas de Buenos Aires, al articular texto e imagen e incorporar la publicidad, que había sufrido desde la década del noventa una explosión con el aumento de la proporción asignada y nuevas resoluciones estilísticas. Esta cultura visual didáctica acompaña textos sobre la enseñanza de algunas disciplinas escolares: geometría o dibujo, textos sobre zoología, flora o astronomía acompañadas con indicaciones para su uso en el aula. Simultáneamente con la aparición de las ilustraciones, las fotografías comienzan a tener un lugar relevante, sobre todo las que registran temas variados: edificios escolares, el territorio en toda su extensión, ciudades y paisajes argentinos, actos y excursiones escolares. ${ }^{30}$

29 Ministerio de Justicia e Instrucción Pública, “El Monitor”. Año I, Núm. 1, Buenos Aires, septiembre 1881.

30 Paula Félix-Didier y Sandra Szir, "Ilustrando el consumo. La relación texto-imagen en los avisos de publicidad gráfica de las publicaciones periódicas", en Poderes de la imagen editado por CAIA, CD-ROM (Buenos Aires: IX Jornadas CAIA, 2013). 
Esta publicación emblemática emerge como un encuentro del "mundo del texto", de factura convencional de acuerdo con los tonos de las publicaciones oficiales y un "mundo del lector" que instituyen las "comunidades de interpretación", integrado por los cuerpos docentes y estudiantes de todo el territorio nacional e irradiación latinoamericana, los que comparten un conjunto de competencias para el abordaje de los contenidos de diversas procedencias, entre ellos, los provenientes de las Conferencias Pedagógicas (Reglamento de 1887) y las Doctrinales (Reglamento de 1893) producto de intercambios sobre la práctica educativa.

A modo de ilustración, señalamos Enseñanza intuitiva, por Albina García de Ryan; Enseñanza de la lectura, por Esteban Lamadrid; Enseñanza de la escritura, por José Ojeda; Metodología por Andrés Ferreira; Jardines de Infantes por Elena Segot; Ejercicios físicos, por Honorio Leguizamón, que da lugar a una larga polémica con Pablo Pizzurno y El ahorro como institución escolar por Ángela Menéndez.

Circula en el espacio editorial una abundante producción de materiales informativos y de reflexión, de genealogías y orientaciones diversas como:

El Código de Instrucción Primaria, del Dr. Berra, compendio y análisis comparado y artículos sobre la enseñanza del idioma nacional, La enseñanza, la Revista Pedagógica Argentina, editada por el Centro Unión Normalista, con la participaciones de Suárez, Aubin y Sixto, La nueva escuela de Alfredo Ferreyra y Pablo Pizzurno y Sarmiento de Camilo Salinas., La educación de José Zubiaur, Sarfield y Vergara. ${ }^{31}$

El campo editorial es incrementado por la edición de nuevos títulos, autores y lectores, quienes renuevan el estado de la reflexión educativa, como surge del estudio del artículo publicado por el Monitor. En las novedades y críticas, por ejemplo, aparece la propuesta de Víctor Mercante para difundir los avances de la psicología experimental que se articula con la teoría educativa. Otros temas comienzan a problematizarse para luego incorporarse a futuras gestiones, tal como el impulso de la enseñanza industrial por parte del Dr. Zubiaur y el destacado artículo Escuela Profesional para Mujeres de Eduardo Rodríguez Larreta sobre la vinculación educación y trabajo.

31 Marengo, "Estructuración y consolidación del poder normalizador..., 92. 
El nuevo siglo trae nuevos abordajes en la enseñanza, funcionales a la emergencia de la psicología, y reformula al sujeto de la educación y las diversas estrategias didáctica y tendencias político-pedagógicas. Son numerosos los aportes para las diferentes materias y métodos de enseñanza y aprendizaje, la participación política de los maestros y la especificidad de los Territorios Nacionales. Comienzan a producirse discursos educativos democratizadores de corte krausista-espiritualista, favorecidos por las confluencias de positivismos comptianos y las lecturas de Krause, quien reivindicaba las teorías de Pestalozzi y las de Froebel. Circulan en las páginas del Monitor de la Educación por medio de comentarios bibliográficos de las obras editadas:

La Educación Republicana de Carlos Vergara, Enseñanza prácti-
ca e industrial de José Zubiaur, La escuela industrial, de Ramón
Carillo, La Unidad de los métodos pedagógicos, de Rodolfo Sen-
té, los Ensayos sobre la Educación de Dr. Agustín Alvarez, La
educación técnico de la mujer de Cecilia Grierson, Educación
industrial de Agustín Solís y tomando un tema polémico, An-
drés Ferreira publica el Estudio de la ley de jubilaciones del
Magisterio. ${ }^{32}$

Se editan el cronograma de las actividades y producciones de las numerosas asociaciones y sociedades populares, productos del fervor asociativo generalizado en lo político, gremial, étnico y cultural imperante, como la Sociedad Popular de Lomas de Zamora, la Sociedad Popular de la Boca, la Asociación Popular de Amigos de la Educación de Víctor Mercante y Joaquín Mora, iniciativas generadas con el fin de instalar en la esfera pública debates y difusión de temas, abordajes y sentidos en acciones alternativas a los discursos y gestiones oficiales.

El Monitor de la Educación estaba acompañado por la edición mensual de la Revista de Higiene Escolar que incluía discursos sobre la higiene, producidos por una amplia red de médicos, arquitectos y educadores, que con, actuación destacada, aspiraban a cumplir la promoción de los criterios médicos sobre los hábitos de la vida escolar y la cotidiana, y el combate del alcoholismo y tabaquismo en publicaciones como Desviaciones en la columna de origen escolar del Dr. Benjamin Martínez y entre las obras destacadas Males de nuestra raza del Dr. Agustín Álvarez, o Mortalidad en Buenos Aires de Dr. Carrasco.

32 Ibid., 96. 
Esta será la tarea del Cuerpo Médico Escolar (1888) cuyo Reglamento de la Inspección Médica de 1909 dispone:

Que observen fielmente las prescripciones de la higiene... Procederá a practicar el examen individual de los escolares (general, orgánico, antropométrico y psicológico) cuyos datos se asentarán en una ficha o libreta. $^{33}$

Casi con carácter misional se intentaron cumplir con los objetivos y se apeló a la aplicación de recursos para formar a las visitadoras de higiene escolar: clases modelos, conferencias, las gráficas y los libros. Solo a modo de ejemplo:

Francisco P. Súnico, Nociones de Higiene (1902), de Benjamín Martínez, Higiene Escolar (Congreso Médico Latinoamericano de 1907), de Segundo Gallo, Contribución al estudio de la Higiene Escolar (1908), que servirían para su aplicación por fuera del ámbito escolar. ${ }^{34}$

Este campo editorial se verá enriquecido por la producción de originales de los especialistas del ámbito de formación docente que promueven el debate y la provisión de material, al dar cuenta la evolución de las orientaciones en los diseños de las carreras pedagógicas y de los contenidos de las materias, en los sentidos de los discursos que se proponen, los que encuentran eco en la prensa y se debaten en congresos y conferencias doctrinales.

\section{1900-1910: celebraciones y disensos}

El inicio del siglo XX encontró al campo educativo en un período de expansión (1899-1904) del Consejo Nacional de Educación, y del debate de las problemáticas pendientes, entre ellas, la orientación de la enseñanza secundaria y su vinculación con el aparato productivo, en paralelo a las polémicas sobre la implementación de estrategias para una acción nacionalizadora eficiente.

En abril de 1900, en el contexto de una compleja sociabilidad política, una conflictividad creciente de gremios y amplios sectores del trabajo y los

33 Norma Sánchez, La higiene y los higienistas en la Argentina (1880-1943), (Buenos Aires: Sociedad Científica Argentina, 2008), 300.

34 Rafael Gagliano, "Nacionalismo, inmigración y pluralismo cultural. Polémicas entorno al centenario" en Sociedad Civil y Estado en los orígenes del sistema educativo argentino, editado por Adriana Puigros, (Buenos Aires: Editorial Galerna, 1991), 96. 
movimientos del abstencionismo revolucionario radical, desde las páginas del Monitor se interrogaba a un normalista reconocido, José Zubiaur, en “¿Cómo debemos festejar a Mayo?”. En 1902, ante las preocupaciones surgidas de la valoración del proceso de homogenización propuesto por el sistema educativo como deficiente, las autoridades se propusieron enfrentar una tarea urgente:

Encontrar las formas adecuadas para que estos héroes y epopeyas recreados se encarnasen en la sociedad. El problema radicaba, precisamente, en establecer que ámbitos y a través de que canales - en una sociedad que se rehacía día tras día- podían los recién llegados o los más jóvenes vincularse con el pasado argentino, al cual se remitían los rasgos de la identidad nacional. ${ }^{35}$

En estos sentidos, se había dispuesto la exhibición del escudo y la bandera, y la obligatoriedad de la celebración del 25 de Mayo y del 9 de Julio, liturgias patrióticas que adquirirán carácter sistemático y un énfasis creciente. En 1904, el gran educador Pablo Pizzurno, Inspector General de Escuelas, escribió en su Memoria anual del Consejo Nacional de Educación sobre el estado de la enseñanza en las escuelas de la ciudad de Buenos Aires, sus reflexiones acerca de “¿Cómo se forma al ciudadano?" y expuso una visión muy diferente de la que finalmente se impuso en la liturgia escolar:

Hablemos de la patria como ciudadanos que la aman y mucho, pero como ciudadanos a quienes el patriotismo no les pone una venda ante los ojos, [...] Hablemos de la patria como educadores obligados a servirla no con frases enfáticas y explosiones patrioteras, a fecha fija, en Mayo y en Julio ${ }^{36}$

El estado nacional argentino, luego de Caseros, de manera paulatina, explicita que esos acontecimientos fueron la Revolución de Mayo y la Guerra de la Independencia: los denominados "sucesos de Mayo de 1810", acontecimientos que adquirieron bajo múltiples representaciones los más variados lenguajes y formas, configuradas de acuerdo con una diversidad de procesos simbólicos específicos, que tomaron como objeto a la Revolución de Mayo, le asignaron la calidad de acontecimientos fundantes y los proyectaron utópicamente

\footnotetext{
35 Lía Ana Bertoni, “Construir la Nacionalidad: Héroes, Estatuas y Fiestas Patrias, 1887-1891” en Boletín del Instituto de Historia Argentina “Dr. Emilio Ravignani”, (Buenos Aires: Facultad de Filosofía y Letras, 1992$), 97$.

36 Ema Cibotti y Sergio Lischinsky, La idea de la independencia en el discurso histórico, entre la Academia y la divulgación, (inédito).
} 
hacia el futuro, al que convirtieron en destino de la colectividad que se debía reconocer como la nación argentina, una república liberal nacida en mayo.

El mito de origen asignado a Mayo es una operación simbólica que participa de alguna de las características de los fenómenos que se verifican en los procesos de construcción de naciones poscoloniales, mitos cuyos contenidos y sentidos específicos emergen en ocasiones de la historiografía, en de una trama de la circulación de relatos, memorias sociales y prácticas culturales.

Este mito establece una versión de los hechos reales o imaginarios que brinda sentido y legitimidad a determinados acontecimientos y protagonistas fundantes, en los nuevos regímenes se establecerá como verdad una solución vencedora contra las fuerzas del pasado que posibilitara la elaboración de otro mito: el mito del héroe, de larga tradición en las historias nacionales y funcional a todo régimen que busca instalar un panteón cívico y destacar figuras que sirvan de imagen y modelo para los miembros de una comunidad. Entre 1908-1813, preside el Consejo Nacional de Educación el Dr. José M Ramos Mejía, de importante trayectoria en el campo de la salud pública y la política. Es director de la Asistencia Pública, presidente del Departamento Nacional de Higiene, "diputado Nacional de las masas", formula en Las multitudes argentinas (1899) sus posiciones sobre la formación del temperamento nacional, propone a la escuela "pública como resorte de la nacionalización de las masas, desde sus funciones en el Consejo, ya que a pesar de todo, aún los sostenía la confianza de que las pasiones patrióticas podían ofrecer un dique y una cauce a los males de la modernidad". ${ }^{37}$

La percepción de Ramos Mejía del fenómeno de modernización y una "pérdida de sentido" en la sociedad argentina, signada por la heterogeneidad y "movilizada por valores económicos" que atentan contra la virtud republicana, es evaluada como una anomia patriótica y presagio de una decadencia nacional que conducirá a la "ausencia de la multitud política y a quitarnos la fisonomía nacional" ${ }^{38}$

En 1908 se dispuso como hito explicativo en el calendario de efemérides escolares, "la semana de Mayo", el uso de retratos de los próceres en las aulas y en 1909 se instituyó como obligatoria la Jura de la Bandera. El dispositivo

37 Mariano Plotkin, “Política, educación y Nacionalismo en el Centenario", Todo es Historia 221, (1985): 70.

38 José María Ramos Mejía, Las multitudes argentinas, (Buenos Aires: TOR, 1899), 30. 
didáctico y pedagógico al que aspiraba Pizzurno estaba muy distante de aquellas otras voces que en la misma época ganaban predicamento y que veían en la "educación patriótica" un tributo al nacionalismo de los hombres que rodeaban el Consejo de Educación.

El reemplazante de Pizzurno fue Ernesto Bavio, quien asumió en 1909 y cuyas ideas estaban en las antípodas. Según él, en torno de Mayo había que enseñar:

Problemas concretos en los que se haga mención a fechas de batallas, al número de patriotas antes y después de entrar en combate, al nacimiento y muerte de algún prohombre, a las fechas en que se reunieron las distintas Asambleas. ${ }^{39}$

El profesor Ernesto Bavio es un arquetípico maestro normal, egresado de Escuela de Paraná, quien ha desarrollado el cursus honorum de la carrera docente en la provincia de Entre Ríos, donde en 1887 instaló la educación patriótica. Generó una "suerte de catecismo de la doctrina cívica, donde se fundían ideas patrióticas y religiosas, más tarde, obligatorio al reglamentarse el plan de estudio para las escuelas primarias, cuando fue nombrado Inspector General de Escuelas de la Provincia". ${ }^{40}$ En este horizonte de ideas, el Estado comisiona a Ricardo Rojas la redacción de un informe sobre educación, relativo específicamente a las ciencias históricas, luego de realizar una gira por establecimientos educativos europeos. Publicado en 1909 con el título $\mathrm{La}$ Restauración Nacionalista, nos explica el autor en el prólogo de 1922 cuando "ha cambiado el ambiente de nuestra patria y donde aún es larga de la senda abierta al nuevo ideal de argentinos", pero en 1910, su texto fue rodeado de

un largo silencio sucedió a su aparición de un extremo a otro del país predominaba en toda la República esa actitud de escepticismo y egoísmo que el último capítulo señala en un cuadro recargado de sombras y no exento de verdad. ${ }^{41}$

Esta emblemática obra es la expresión de la respuesta ante una supuesta crisis de valores que ha causado el proyecto liberal modernizador, la masiva

39 Plotkin, "Política, educación y Nacionalismo en el Centenario", 70.

41 Ricardo Rojas, La restauración nacionalista, (Buenos Aires: Peña y Lillio Editor, 1917), 17. 
presencia de inmigrantes y el agotamiento del modelo agroexportador, con la intensificación de la modernización y la racionalidad económica, la urbanización y el cosmopolitismo de las prácticas culturales que habían permeado la conciencias individuales y modificado su ethos cultural.

Las premisas de intelectuales de este sector, que confluyen en el "nacionalismo integral", luego diversificado, enuncian el compromiso entre el interés expresivo de resolución estética-literaria y la política, que encuentra en la tradición, no una función nostálgica, sino identificatoria de una construida etnia criolla, originada en un pasado mítico, conservada libre de contaminación en estado de pureza, tradición convertida en temática central de la reflexiones y programas de acciones, una nación etnográfica que encontrará lenguajes literarios y estéticos con sentidos diferentes en Gálvez, Quiroga y Lugones.

El carácter sistemático y creciente de la orientación patriótica de estas políticas no encontró críticas sistematizadas en la denominada "cultura científica" y sectores políticos, en el contexto de la campaña por la nacionalización del partido socialista, la reforma militar y las propuestas de reformas electorales que apuntaban a objetivos integradores y nacionalizadores, entre estas, la impulsada por Ramos Mejía.

Esta educación patriótica, que apelaba al mito de los orígenes asignado a "los sucesos de Mayo", y propuesto por los contenidos de los sucesivos textos seleccionados para la enseñanza, en una operación simbólica, por la cual un acontecimiento multidimensional se establecerá como verdad, una solución vencedora y moralizadora contra las fuerzas del pasado y la heterogeneidad de procedencias de los sujetos pedagógicos.

La amplia circulación que garantiza el sistema educativo instituye la condición de posibilidad de la elaboración de otro mito, el mito del héroe, de larga tradición en las historias nacionales y funcional a todo régimen que busca instalar un panteón cívico y destacar figuras que sirvan de imagen y modelo para los miembros de una comunidad. ${ }^{42}$

42 Benedict, Comunidades imaginadas, 45. Hobsbawm y Ranger, La invención de la tradición, 20. 
En estos sentidos Ricardo Rojas afirma:

[...] el profesor de Historia -el maestro normal- no ha de ser, a tal fin, básicamente docente, sino moralista. En la educación, ese aspecto moral de la historia, siendo inherente a las biografías, interesa más bien en la enseñanza primaria, donde ese habla más bien a la imaginación, donde los héroes tienen un valor simbólico. ${ }^{43}$

En 1889 el doctor Adolfo P. Carranza, había fundado el Museo Histórico de la Capital, luego Nacional, cuyas visitas fueron promocionadas por los pedagogos y recomendadas en El Monitor de la Educación como soporte de la enseñanza de la historia:

[...] el museo se había convertido en la sede ceremonial del Patrimonio, sustentando a un discurso histórico-museográfico, condensado en objetos y grandes cuadros, cuya exhibición y difusión organizaba las vinculaciones simbólicas que enunciaban las argumentaciones sobre un relato de la historia nacional, y definian a una topografía memorial hegemónica. ${ }^{44}$

En los decenios siguientes, con el propósito de difundir las representaciones de esta genealogía de la República, se elaboraron producciones culturales, definidas a partir de una iconografía modélica, estableciendo un repertorio de imágenes y esculturas revestidas del sentido histórico asignado.

La construcción de estos patrimonios en la acción del Estado implica complejas circulaciones de ideas y proyección de intereses, tanto en la adopción de estrategias de su producción y ejecución de los memoriales (museos y monumentos), así como también en las condiciones de las posteriores políticas de gestión cultural, al aplicarse una determinada selección de valores para disponer de su preservación y su circulación, de acuerdo con la evolución de diversas estrategias comunicacionales. ${ }^{45}$

Desde el campo educativo, se compartían los sentidos del uso didáctico de los patrimonios iniciados desde variados coleccionismos. Así, en 1885 se dis-

43 Gagliano, "Nacionalismo, inmigración y pluralismo cultural", 286.

44 María Inés Rodríguez Aguilar y Miguel José Ruffo, "La Gestión Patrimonial del Estado y la Construcción de Identidades: el caso de Pedro Subercasaux", en Espacio Público, Patrimonio e Identidad en América Latina, editado por Denis Ramirez Losada, 263277. (México: Instituto de Ciencias Sociales y Humanidades Alfonso Vélez Pliego, Universidad Autónoma de Puebla, 2007 ), 263.

45 María Inés Rodríguez Aguilar y Miguel José Ruffo, "Las memorias de Mayo. La construcción de su repertorio iconográfico en lo celebratorio y lo festivo, 1810,1910, 2010", Temas de Patrimonio Cultural 27. Comisión para la Preservación del Patrimonio Histórico Cultural de la Ciudad de Buenos Aires, (2009), 205-268. 
puso la creación de un Museo Escolar Nacional, luego asignado a la Biblioteca de Maestros. En paralelo, en 1910, concurrieron a esta esfera urbana de Buenos Aires múltiples iniciativas monumentales de diversas procedencias y objetivos, como el horizonte postulado por Ricardo Rojas sobre "pedagogía de las estatuas", estrategia didáctica y propuesta de reparación al agravio que significó la instalación de las estatuas de Mazzini y Garibaldi, mediante la realización de esculturas y monumentos portadores de valores nacionales, reafirmado en su discurso La escuela Argentina en la Escuela Normal para Maestras.

En oposición al postulado rojiano, se sostiene que las raíces de la nacionalidad se encontraban en la historia, reacciona Juan Álvarez y afrima que "el punto débil de este proyecto estriba en que el pasado, lejos de ser una entidad fija e inmutable, varió sin cesar, como el presente [...]y no ofreció la población argentina aspectos de nacionalidad compacta". ${ }^{46}$

En este disenso, Juan Álvarez cuestiona en las premisas de Rojas no solo su conceptualización cristalizada y estática de la nacionalidad que "no son otra cosa que aspectos movedizos y cambiantes" sino que además establece que la construcción de la idea de nación se infiere desde el presente y desde una concepción racional, "basada en la incorporación efectiva de los inmigrantes a la vida política", formulaciones que visibilizan en el debate la crisis del modelo político conservador, la legitimidad de su representación y las condiciones del ejercicio ciudadano.

En confluencias y tensiones se despliega "la querella de la nacionalidad" que demanda que estos dilemas que atraviesen al "cuerpo social" en los términos de Bunge (Nuestra América), José Ingenieros (Lecciones de Sociología) y José M Ramos Mejía (Las multitudes argentinas) quienes ejercieron funciones dirigentes y cuyas concepciones sostuvieron los sentidos de sus prácticas.

En estos tiempos de efervescencia patriótica, dictan nuevas normativas del Consejo Nacional de Educación para administrar los nuevos panoramas emergidos de la aplicación en todo el territorio de la Ley Lainez de 1905 que en su Art. $1^{\circ}$ establece:

46 Plotkin, "Política, educación y Nacionalismo en el Centenario", 70. 


\begin{abstract}
El Consejo Nacional de Educación procederá a establecer directamente en las provincias que escuelas elementales, infantiles, mixtas y rurales, en las que se dará el mínimun [sic] de enseñanza establecido en el Art. 12 de la Ley 1420 del 8 de julio de 1884. ${ }^{47}$
\end{abstract}

En esta nueva etapa de creciente centralización y control del Consejo Nacional de Educación de la gestión Ramos Mejía, en una realidad de mayores especificidades y complejidades (consecuencia de la Ley Lainez) se adoptaron ciertas medidas, como exoneraciones y medidas disciplinarias, motivando algunas situaciones polémicas, las que repercutieron en la prensa y en el Consejo (las sonadas renuncias de Zubiaur y Berruti). Emergió así una multiplicidad de tensiones latentes que interpelaban a la hegemonía de corte autoritario, ejercida por el estado, que revisaban la relación educación y Nación y debatía las muy diferenciadas concepciones del sujeto pedagógico.

\title{
5. Otras voces en las experiencias pedagógicas: socialistas y anarquistas
}

Desde fines del siglo XIX, la sociedad argentina se había integrado al mercado mundial, en calidad de proveedora de materias primas agropecuarias, posibilitando el origen del proletariado moderno, que a principios del siglo XX contaba solo con dos organizaciones gremiales, la Federación Obrera Regional Argentina en 1904 (FORA), de tendencia anarquista y socialista; y la Unión General de los Trabajadores (UGT), primero socialista y después sindicalista, en 1909, quienes participaron fervorosamente del fenómeno del "diarismo" y del asociacionismo.

A partir de 1876, los socialistas se conformaron como un partido político proponiendo luchar por el ejercicio de la democracia política, defender los derechos de las minorías políticas, luchar por una legislación social, protectora de los derechos de los trabajadores, la independencia del país y modificar su estructura económica y de clases. Su fundador fue Juan B. Justo, líder intelectual y autor de Teoría y Práctica de la Historia (1909), que trazó un enfoque biológico de la historia, de acuerdo con la cual Argentina podía ser comparada con una entidad en crecimiento. Proceso que los socialistas debían ayudar a completar en los sentidos del proyecto sarmientino: laicidad

47 Gianello, "La enseñanza Primaria y secundaria (1862-1930)", 134. 
y expansión de la educación (especialmente en el sector rural) para consolidar una cultura cívica.

El discurso socialista sostuvo la idea de un Estado docente fuerte, que concentrara los procesos educativos de la generación infantil, pero al mismo tiempo promovieron las iniciativas de la sociedad civil, al potenciar la participación de mujeres y la creación de asociaciones populares de educación con estos objetivos.

En la inauguración del La Sociedad Luz, en 1908, el Dr. Damianovich, su secretario, sintetizó el "ideal", afirmando: "La educación e instrucción gratuita del pueblo, dar al pueblo lo que pertenece como parte integrante de la familia humana", y puso énfasis en la desigualdad entre las condiciones de los niños obreros y los hijos de las burguesías, en el contexto del debate y regulación del trabajo infantil.

Temática compartida por socialistas y anarquistas desde los abordajes del higienismo y de la argumentación eugenésica respecto de los niños percibidos por el senador socialista Alfredo Palacio, en la Ley $N^{o} 5291$ del trabajo de mujeres y menores, como "depositarios del porvenir de la patria, que debían formar una juventud sana alegre e incontaminada" a partir de su regeneración por el trabajo.

El socialismo centró sus discursos y acciones en la "cuestión social infantil", preocupación del sistema educativo, en las que confluyeron socialistas y pedagogos y maestros krausistas, quienes incorporaron sus concepciones del niño, la importancia del análisis de las dimensiones psicológicas y médicas de la infancia.

De acuerdo con propuesta del alemán August Bebel en obra "La mujer y el niño" se expone un discurso educativo disidente que proponía como meta la autonomía del niño, un sujeto libre que había recibido "la educación racionalista" por medio escuelas particulares, que cortara la "cadena de la esclavitud". En uno de los artículos de La voz de la mujer se desarrollaba la idea de una educación antítesis de la educación familiar y pública. ${ }^{48}$

48 Dora Barrancos, Mujeres en la sociedad argentina. Una historia de cinco siglos, (Buenos Aires: Editorial Sudamericana, 2005), 132 y 168. Sandra Carli, Niñez, Pedagogía y Política, 78. 
Anarquistas y socialistas formularon diversas y tangenciales concepciones de estrategias para democratizar el campo, desde valoraciones diferenciadas de los roles del Estado, de las interpretaciones del statu del niño y de las especificidades del proceso pedagógico.

El discurso socialista se pronunció en defensa de la escolaridad estatal con orientaciones provenientes del positivismo, vinculado al higienismo social. Paralelamente, la radicalidad del discurso anarquista proponía la disolución de la asimetría entre el adulto y el niño, considerados como sujetos con derechos propios y habilitados para participar activamente en la lucha contra la opresión del estado y los poderosos.

Las prácticas militantes del anarquismo intentaron articular un proyecto educativo alternativo, ya que postulaban a la educación como una función relevante en los dispositivos ideológicos de la construcción de la identidad de los trabajadores, apoyado en "conceptos que combatían el patriotismo, el militarismo, el clericalismo desde el racionalismo como doctrina educativa", pues se perseguía contrarrestar las modulaciones de la educación patriótica estatal. Según Suriano las experiencias educativas libertarias "fueron fragmentarias, discontinuas" ${ }^{49}$ y de escasa viabilidad, no alcanzando la eficiencia perseguida, quizá por los límites del discurso y la acción libertaria y la condición deseable y novedosa de su propuesta para los sectores para las que estaba destinada.

Un amplio sector de la sociedad argentina era de origen italiano, cuya dirigencia generó un sistema de escuelas de socorros mutuos (1866-1914) con el objetivo de satisfacer las demandas educativas instrumentales y consolidar los vínculos con Italia, lo que generó una fuerte polémica y resistencia al ser percibidas como una amenaza para la cultura nacional, en especial con Sarmiento.

Las escuelas italianas emergieron indemnes de esta polémica, ya que según el informe de CNE de 1889 "prestan buenos servicios". Su evolución y vigencia están vinculados al caudal migratorio, por lo tanto en el proceso de asimilación intransigente del estado hacia 1905, los cálculos sobre las escuelas de

49 Juan Suriano, Cultura y política libertaria en Buenos Aires (Buenos Aires: Manantial, 2001), 219-225. 
la Capital estiman que "hay por lo menos 25000 chicos italianos de los cuales solamente frecuentan 2855 frecuentan escuelas italianas". ${ }^{50}$

En un amplio horizonte de ideas, circularon debates y los intercambios de una pluralidad de vertientes que contaron con la participación de un amplio y calificado abanico de profesionales, entre estos, Raquel Camaña, miembro activo de la Liga Nacional de Maestros, quien produjo una verdadera propuesta renovadora: la "pedagogía social". Maestra normal y egresada universitaria, fue propagadora de la escuela maternal, las salas cunas, institutos de puericultura y de la difusión de la maternología, delegada al Congreso de Higiene de París de 1910 y autora de un texto medular en Educación Integral, extraído de su conferencia contra el clericalismo y el auge de las posiciones nacionalistas, en homenaje a Francisco Ferre Guardia.

Con otra orientación, Julio Barcos, docente y militante gremial fundador de la Liga Nacional del Maestro en 1910, declarado admirador de Sarmiento, ejerció en Escuelas de la Liga Racionalista y formuló críticas implacables al positivismo normalista y a los nacionalistas y católicos, tanto a sus gestores como de sus intelectuales, al régimen conservador y a la burocracia política del sistema educativo "que se encontraba abroquelado en el Consejo Nacional de Educación y sus órganos dependientes en todo el territorio". ${ }^{51}$

Los congresos-plenarios se instituyeron como ámbitos de intercambios y debates de saberes y proposiciones, que se transmiten a las comunidades de incumbencias y pertenencias con el propósito de influir en los diferentes campos de la acción política. Con estos sentidos se realizó en Buenos Aires, desde comienzos de siglo, una diversidad de congresos nacionales e internacionales.

Alrededor del centenario se llevaron a cabo, entre otros, El Congreso Internacional del Libre Pensamiento, Los Congresos de Bibliotecas Populares y Sociedades Populares de Educación, los Científicos Internacional e Interamericanos, el Congreso de Americanistas y el Oficial Primer Congreso Patriótico de Mujeres y el Congreso Internacional Feminista, los dos últimos tratan la condición femenina en sus aspectos integrales, el primero desde

50 Luigi Favero "Las escuelas de las sociedades italianas en Argentina", en La inmigración italiana en la Argentina, eds. Fernando Devoto y Gianfausto Rosoli (Buenos Aires: Biblos, 1985), 165-205.

51 Adriana Puiggrós, Sociedad Civil y Estado en los orígenes del sistema educativo argentino (Buenos Aires: Editorial Galerna, 2005), 218. Sandra Carli, Niñez, Pedagogía y Política, 168. 
la mirada católica de la élite y el segundo desde los reformismos laicos, el socialismo, anarquismo y el libre pensamiento, coincidiendo en una cuestión, el maternalismo "el síndrome de las identificaciones con un modo de ser femenino basado en la experiencia de la maternidad y en su apología". ${ }^{52}$

El Congreso Internacional Feminista implementó una Sección de Educación, Letras, Artes e Industrias de veintiocho títulos. Algunos textos reafirman, en concordancia las autoras socialistas y anarquistas, los postulados de coeducación al compartir una argumentación eugenésica con interpretaciones positivistas y con interpretaciones morales sobre los males de la sociedad. Entre otros temas en el clima de nacionalismos imperantes la Dra. Ernestina López expuso Clases para niños inmigrantes que, luego de su tratamiento, obtuvo la siguiente conclusión:

El Congreso Feminista Internacional formula un voto porque las autoridades escolares, establezcan, exclusivamente destinadas a los niños inmigrantes y cuya tarea consista en enseñarles la legua del país sin cuyo requisito no podrán concurrir a las escuelas primarias ${ }^{53}$

Desde el espectro de complejas visiones de la sociedad, el socialismo y el anarquismo, y sus vertientes en clave de postulados feministas, interpelaron y cuestionaron a los núcleos del campo educativo que celebró al Centenario, caracterizado por la hegemonía del estado y la implementación de políticas nacionalizantes.

\section{CONCLUSIÓN}

En el escenario de la Buenos Aires de 1910, capital de la euforia, se editó, en conmemoración al Centenario de 1810, la monumental Historia de la Instrucción Primaria de la República Argentina 1810-1910 (Atlas Escolar) proyectada por el Presidente del Consejo Nacional de Educación, Dr. José María Ramos Mejía. Compilada y redactada por Juan. P. Ramos Inspector general de Provincia.

El discurso oficial enunciado en el texto, a la par que mirada historiográfica, es síntesis argumentativa de las finalidades del Consejo: un inventario de las

52 Dora Barrancos, Mujeres en la sociedad argentina, 134.

53 Universidad Nacional de Córdoba, "Primer Congreso Femenino Buenos Aires 1910" (Córdoba, Universidad Nacional de Córdoba), 121. 
cuestiones en debate y polémicas de ese presente, entre ellas, La escuela y la nacionalidad, redactado para

elaborar una fragmentaria contribución a la historia nacional, donde la historia de la educación ofrece una desesperante falta de narración. Aquí se dispone de una sola nota vibrando en una sola cuerda,... falta también la sensación interna, el sentimiento colectivo del pueblo, sustentador de la escuela. ${ }^{54}$

Un balance más integral mostrará un crecimiento desigual del progreso educacional, por regiones y niveles educativos, que no logró una vinculación eficiente entre sector productivo y contenidos de la enseñanza, sin plasmar una articulación entre las esperanzas provenientes de "el baúl de inmigrante" y sectores criollos, y formas de inserción socio-económica y políticas, más democráticas e igualitarias, ${ }^{55}$ deudas y reclamos que incluirán a sectores medios interesados en una educación y una cultura progresista y a los sectores anarquistas y socialistas.

Es esta publicación es un registro minucioso de la dinámica burocrática y sus avatares, y una valoración de estado del patrimonio documental y oral público y privado de "documentos, referencias, folletos, tradiciones que me han servido, archivos que hemos revisado con benedictina paciencia, y aclarando que mejor fuente he tenido en las referencias personales de viejos vecinos". ${ }^{56}$

La exitosa consolidación del sistema educativo nacional se integra conjuntamente con las especificidades que brindan las instituciones de comunidades étnicas, los sectores confesionales (católicos y protestantes) de fuertes emprendimientos y las orientadas por pensamientos divergentes de las concepciones pedagógicas democratizadoras, vinculadas y sostenidas por las amplias redes asociativas, lo que posibilita la participación de la sociedad civil, que demandarán y orientarán a los futuros cambios.

54 Historia de la Instrucción Primaria de la República Argentina 1810-191, (Atlas Escolar) Proyectada por el Presidente del Consejo Nacional de Educación, Dr. José María Ramos Mejía. Compilada y redactada por Juan .P. Ramos Inspector General de Provincia, (Buenos Aires: Peuser, 1910), 12.

55 María Inés Rodríguez Aguilar, El campo migratorio argentino: su especificidad y el abordaje teórico- metodológico del género (en prensa).

56 Historia de la Instrucción Primaria de la República Argentina 1810-191, (Atlas Escolar) Proyectada por el Presidente del Consejo Nacional de Educación, Dr. José María Ramos Mejía. Compilada y redactada por Juan .P. Ramos Inspector General de Provincia, (Buenos Aires: Peuser, 1910), 9. 
Sistema que era objeto de reflexiones y análisis por los visitantes de celebración del Centenario para Georges Clemenceau (1841-1929) senador, ministro y un periodista excepcional cuyos artículos eran seguidos por lectores argentinos. Recuperemos algo de su síntesis reveladora:

Nada tiene de extraño que me haya llamado la atención las escuelas. He visto escuelas profesionales (Escuela Industrial de la Nación) y escuelas primarias que podrían servir de modelo a otros países [...] Un centenar de escuelas privadas, laicas o confesionales, [...] que recogen los niños que no pueden entrar a las escuelas públicas. En Buenos Aires, como en el resto del territorio, la cifra de estos excluidos es enojosamente obligada, en todo el territorio el déficit de establecimientos escolares es tal que constituye un verdadero escándalo en una nación civilizada [...] Nada diré de las escuelas y colegios secundarios $[\ldots]^{57}$

En la complejidad del horizonte ideológico pedagógico, heredero del sujeto sarmientino y con un clima de profundos debates y de articulaciones múltiples, con acuerdos implícitos, circularon las tendencias nacionalistas (de cuño católico y laico) junto a las resignificaciones de la tradición positivistanormalista, renovadas con influencias krausistas y espiritualistas de Vergara y Mercante, Zubiaur, las orientaciones más radicalizadas anarquistas y socialistas de Barcos y Senté, y las propuestas educativas del feminismo.

Desde 1884, y luego de la sanción de la Ley 1440, la adopción de políticas públicas y las alternativas educativas orientadas por sectores divergentes confluyeron en la dinámica de la construcción de una sociedad argentina en proceso de escolaridad creciente, definiendo al sujeto pedagógico (objeto de todos los niveles de la enseñanza) de manera diferenciada.

La diversidad de los sujetos emergentes de estos complejos procesos educativos, hacia el centenario, se habían transformado en los actores sociales partícipes de un nuevo proceso, la transición del régimen conservador, acosado por fuertes convulsiones urbanas reclamando demandas sociales de una mejor distribución de las riquezas y las políticas, aspirando a mayor participación ciudadana y a lograr legitimidad en la representación.

57 Georges Clemenceau, La Argentina del Centenario. Prologó de Rogelio García Lupo (Buenos Aires, Universidad Nacional de Quilmes, 1999), 62-65. 
Un sector de estos actores sociales (masculinos mayores de 18 años) en 1916 votarán con el imperio de la Ley Sáenz Peña de sufragio universal, dando el triunfo a Hipólito Irigoyen de Unión Cívica Radical, iniciándose así una nueva etapa que debía atender reclamos de amplio espectro, entre ellos los provenientes del campo educativo, que revitalizarán a sus antiguas tensiones pero también a sus acuerdos, en el debate de la reforma educativa Saavedra-Lamas.

\section{REFERENCIAS}

Anderson, Benedict. Comunidades imaginadas, Reflexiones sobre el origen y la difusión del nacionalismo. Buenos Aires: Fondo de Cultura Económica, 2000.

Bertoni, Lía Ana. Patriotas, cosmopolitas y nacionalistas. La construcción de la nacionalidad a fines del siglo XIX. México: Fondo de Cultura Económica, 2001.

Bertoni, Lía Ana. “Construir la Nacionalidad: Héroes, Estatuas y Fiestas Patrias, 18871891". Boletín del Instituto de Historia Argentina "Dr. Emilio Ravignani", (Primer Semestre de 1992): 77-111.

Bonaudo, Marta y Sonzogni, Élida. “ Los grupos dominantes entre la legitimidad y el control". En Nueva Historia Argentina Tomo IV. Editado por Marta Bonaudo, 27-96. Buenos Aires: Sudamericana, 1999.

Braslasky, Cecilia. Los usos de la historia en la educación argentina: con especial referencia a los libros de textos para las escuelas primarias 1853-1916, Serie de Documentos e informes de Investigación $N^{\circ}$ 133. Buenos Aires: FLACSO, 1992.

Carli, Sandra. Niñez, Pedagogía y Política. Transformaciones de los discursos acerca de la infancia en la historia de la educación argentina entre 1880-1945. Buenos Aires: Universidad de Buenos Aires y Miño y Dávila, 2005.

Cassani, Juan. Doctrinas pedagógicas de Sarmiento. En Humanidades, Tomo XXVI, editado por Universidad Nacional de la Plata, 57-72. La Plata: Facultad de Humanidades y Ciencias de la Educación de la Universidad de La Plata, 1938.

Ciafardo, Eduardo. “Sobre la educación patriótica. Algunos comentarios acerca de `El fracaso del proyecto Argentino"". En Anuario IEHS, Editado por Universidad Nacional del Centro de la Pcia. de Buenos Aires, 351-360. Buenos Aires: Instituto de Estudios Históricos Sociales, Tandil, Universidad Nacional del Centro de la Pcia. de Buenos Aires, 1991.

Cibotti, Ema. "Del habitante al ciudadano. La condición del inmigrante: La llegada". En Nueva Historia Argentina. El progreso, la modernización y sus límites (1880-1916). Tomo V, editado por Mirta Zaida Lobato, 361-408. Buenos Aires: Sudamericana, 2000.

Cibotti, Ema y Sergio Lischinsky. La idea de la independencia en el discurso histórico, entre la Academia y la divulgación, (en prensa). 
De Diego, José Luis. Editores y politicas editoriales en Argentina 1880-2000. Buenos Aires: Fondo de Cultura Económica, 2010.

Devoto, Fernando. Nacionalismo, fascismo y tradicionalismo en la Argentina moderna. Una historia. Buenos Aires: Siglo XXI, 2002.

Devoto Fernando y Héctor Otero. "Veinte años después una lectura sobre el crisol de razas, el pluralismo cultural y la historia nacional en la historiografía". Estudios Migratorios, Latinoamericanos, Año 1, 50 (2003): 181-227.

Devoto, Fernando y Nora Pagano. Historia de la Historiografía, Argentina. Buenos Aires: Sudamericana, 2009.

Di Tella, Torcuato. "Raíces de la controversia educacional en la Argentina”, Trabajo e Investigaciones del Instituto de Sociología, Facultad de Filosofía y Letras, Publicación Interna Nº77, sin numero.

Escudé, Carlos. El fracaso del proyecto argentino. Educación e ideología. Buenos Aires: Instituto Torcuato Di Tella, 1990.

Eujenian, Alejandro. "La cultura: público, autores y editores". En Nueva Historia Argentina Liberalismo, Estado y Orden Burgués Tomo IV, editado por Marta Bonaudo, 545-605. Buenos Aires: Sudamericana, año 1999.

Gagliano, Rafael. “Nacionalismo, inmigración y pluralismo cultural. Polémicas entorno al centenario". En Sociedad Civil y Estado en los orígenes del sistema educativo argentino, editado por Adriana Puiggros, 281-308. Buenos Aires: Editorial Galerna, 1991.

Gianello, Leoncio. “La enseñanza Primaria y secundaria (1862-1930)”. En Historia Argentina Contemporánea (1862-1939), Vol. II Historia de la Instituciones, editado por Academia Nacional de la Historia, 130-148. Buenos Aires: Academia Nacional de la Historia, 1964.

Halperin Donghi, Tulio. El Espejo de la Historia. Buenos Aires: Sudamericana, 1987.

Halperín Donghi, Tulio. "Vicente Fidel López, Historiador". En Ensayos de Historiografía, editado por El cielo por asalto, 35-45. Buenos Aires: Ediciones El cielo por asalto, 1996.

Hobsbawm, Eric y Terence Ranger. La invención de la tradición. Madrid: Crítica, 2002.

Lobato, Mirta Zaida. "Estado, gobierno y política en el régimen conservador". En Nueva Historia Argentina T.5, editado por Mirta Zaida Lobato, 179-208. Buenos Aires, Sudamericana, año 2000.

Madero, Roberto. El origen de la Historia, sobre el debate entre Vicente Fidel López y Bartolomé Mitre, Buenos Aires: Fondo de Cultura Económica, 2001.

Mantovani, Juan et al. Sarmiento, educador, sociólogo, escritos y político. Buenos Aires: Universidad de Buenos Aires, Facultad de Filosofía y Letras, 1961.

Marengo, Roberto. "Estructuración y consolidación del poder normalizador: el Consejo Nacional de Educación". En Sociedad Civil y Estado en los orígenes del sistema educativo argentino, editado por Adriana Puiggrós, 71-176. Buenos Aires: Editorial Galerna, 1991. 
Memoria de Instrucción Pública, Tomo II. Buenos Aires: Peuser, 1886.

Plotkin, Mariano. "Política, educación y Nacionalismo en el Centenario". Todo es Historia 221 (1985): 65- 80.

Podgorny, Irina. Arqueología de la educación. Textos, indicios, monumentos. Buenos Aires: Sociedad Argentina de Antropología, 1999.

Puiggrós, Adriana. Escuela, Democracia y Orden. Historia de la Educación en la Argentina (19161943) III. Buenos Aires: Editorial Galerna, 1992.

Puiggrós, Adriana. Sociedad civil y Estado en los orígenes del sistema educativo argentino. Historia de la Educación en la Argentina II. Buenos Aires: Editorial Galerna, 1991.

Puiggrós, Adriana. Sujetos, Disciplina y Currículum en los orígenes del sistema educativo argentino (1885-1916). Buenos Aires: Editorial Galerna, 1991.

Primer Congreso Femenino Internacional de la República Argentina. Universidad Nacional de Córdoba, Córdoba, 2008.

Ramos, Juan. "Historia de la Instrucción Pública en la República Argentina (1810- 1910)". En Atlas Escolar, Tomo I Consejo Nacional de Educación Conmemoración del Centenario de 1810, 1-50. Buenos Aires: Peuser, 1910.

Rodríguez Aguilar, María Inés y Miguel José Ruffo. “Las memorias de Mayo. La construcción de su repertorio iconográfico, en lo celebratorio y lo festivo, 1810, 1910, 2010". Temas de Patrimonio Cultural $N^{\circ}$ 27, editado por Comisión para la Preservación del Patrimonio Histórico Cultural de la Ciudad de Buenos Aires, 20-52. Buenos Aires: Comisión para la Preservación del Patrimonio Histórico Cultural de la Ciudad de Buenos Aires, 2009.

Rodríguez Aguilar, María Inés y Miguel José Ruffo. “La Gestión Patrimonial del Estado y la Construcción de Identidades: el caso de Pedro Subercasaux". En Espacio Público, Patrimonio e Identidad en América Latina, editado por Denis Ramírez Losada, 263-277. México: Instituto de Ciencias Sociales y Humanidades Alfonso Vélez Pliego, Universidad Autónoma de Puebla, 2007.

Rojas, Ricardo. La restauración nacionalista. Buenos Aires: Peña y Lillio Editor, 1917.

Sabato, Hilda y Ema Cibotti. "Inmigrantes y Política: un problema pendiente". Estudios migratorios $N^{\circ}$ 4, CEMLA (1986): 475-482.

Sánchez, Norma. La higiene y los higienistas en la Argentina (1880-1943). Buenos Aires: Sociedad Científica Argentina, 2008.

Svampa, Maristella. El dilema argentino. Civilización o barbarie. De Sarmiento al revisionismo peronista. Buenos Aires: Ediciones El cielo por asalto, 1994.

Suriano, Juan. Cultura y política libertaria en Buenos Aires. Buenos Aires: Manantial, 2001.

Szir, Sandra. Infancia y Cultura Visual. Los periódicos ilustrados para niños (1880-1910), Buenos Aires: Miño y Dávila. 2007. 
Tedesco, Juan Carlos. Educación y Sociedad 1880-1945. Buenos Aires: Siglo XXI, 2009.

Terán, Oscar. Ideas en el siglo, Intelectuales y cultura en el siglo XX Latinoamericano. Buenos Aires: Fundación OSDE y Siglo XXI Editores, 2004.

Terán, Oscar. Vida intelectual en el Buenos Aires de Fin de Siglo (1880.1919). Buenos Aires: Fondo de Cultura Económica, 2000.

Zimmerman, Eduardo. Los liberales reformistas. La cuestión Social en la Argentina (1880-1916). Buenos Aires: Editorial Sudamericana y Universidad de San Andrés, 1995.

Rodríguez Aguilar, María Inés; Ruffo, Miguel José. "El centenario y la educación: La épica de la nacionalidad en debate". Revista Historia de la Educación Latinoamericana. Vol. 16 No, 22, (2014): 85 - 120.

EDIFICIOS ESCOLARES

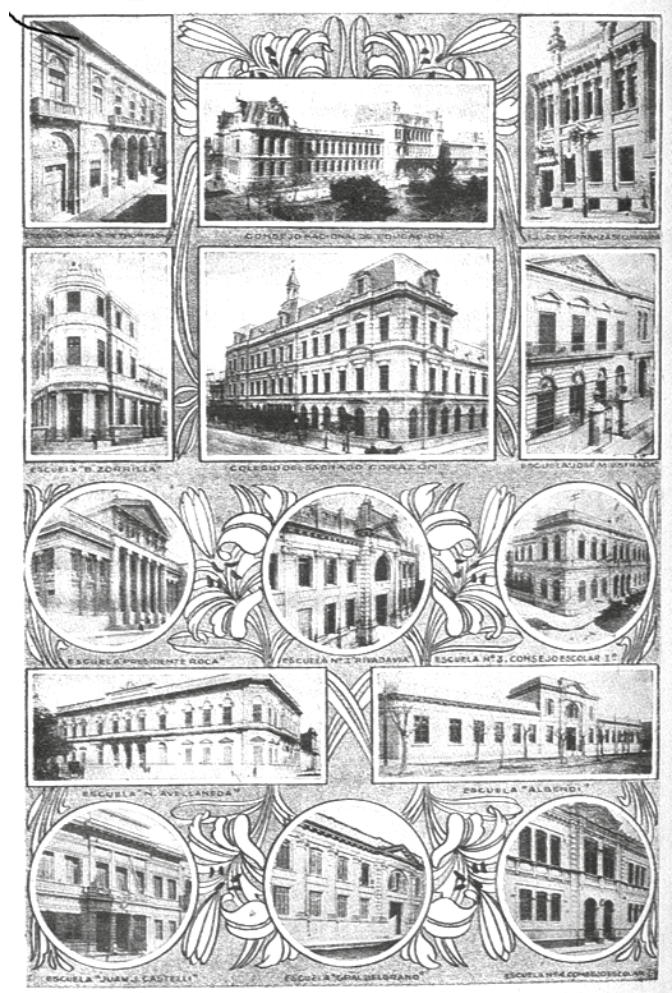

